\title{
Raw vs extruded coloured-flower pea as an ingredient in broiler diets: effects on performance, ileal digestibility, gut morphology, and intestinal microbiota activity
}

\author{
P. Konieczka, S. Smulikowska', J. Czerwiński and A. Mieczkowska \\ The Kielanowski Institute of Animal Physiology and Nutrition, Polish Academy of Sciences, 05-110 Jabłonna, Poland
}

KEY WORDS: pea, extrusion, ileal digestibility, tannins, trypsin inhibitors, short-chain fatty acids, broiler chicken

Received: 19 February 2014

Revised: 2 September 2014

Accepted: 10 September 2014

${ }^{1}$ Corresponding author:

e-mail: s.smulikowska@ifzz.pan.pl
ABSTRACT: Raw or extruded peas (Pisum sativum, pink-flowered cv. Milwa) were used. Extrusion reduced the trypsin inhibitor activity (TIA) from 2.35 to $0.35 \mathrm{mg} \cdot \mathrm{g}^{-1}$, but did not affect tannins content, which was about $1 \mathrm{~g} \cdot \mathrm{kg}^{-1}$. A growth trial was conducted on 200 Ross 308 female broilers from day 1 to 35 of age. There were 3 treatment groups from day 1 to 14 including control without peas, $10 \%$ raw (RP) and extruded (EP) pea. From day 15 birds were kept individually, in groups of 18 , and fed diets containing $15 \%, 20 \%, 25 \%$, or $30 \%$ RP and EP. Chickens fed EP ate more feed $(P \leq 0.05)$ but had similar body weight gains and worse feed conversion ratio $(P \leq 0.05)$ than chickens fed RP. The apparent ileal digestibility (AID) of dry matter was lower in chickens fed EP than RP $(P \leq 0.01)$, whereas AID of protein did not differ. The AID of starch was 0.835 in the control group, in chickens fed both RP and EP it was, on average, 2 percentage points higher $(P \leq 0.01)$. In birds fed RP the short-chain fatty acid concentration in ileal digesta was lower $(P \leq 0.05)$ whereas in caecal digesta higher $(P \leq 0.01)$ than in birds fed EP. The dietary treatments had no effect on jejunal mucosa morphology. Diets containing up to $30 \%$ of peas with a relatively low tannins content and moderate TIA value, can be fed from the third week of life as a partial substitute of soyabean meal in broiler diets. The effects of pea extrusion on ileal nutrient digestibility and activity of gut microbiota was too small to affect performance.

\section{Introduction}

Soyabean meal is the most common source of plant protein used in the commercial poultry feed industry. Due to rising costs of soyabean meal and concerns about genetically modified soyabeans, evaluation of alternative protein ingredients that are locally available and economic is urgently required.

Moreover, it has been shown that feed mixtures with high soyabean meal levels can lead to increased incidence of foot pad lesions in broilers (Nagaraj et al., 2007). Peas (Pisum sativum L.) can offer a valuable source of protein and energy for poultry. Two subspecies of pea are cultivated in Poland: $P$. sativum hortense, which is white flowering and used mainly in human nutrition and as a feed for monogastrics, and P. sativum arvense, which has coloured flowers (pink, red, or purple) and is mainly used in animal nutrition (Gdala et al., 1992). The major antinutritional factors (ANFs) in coloured-flower peas are tannins, trypsin inhibitors and lectins (Huisman and Jansman, 1991; Grosjean et al., 1999), the last two can be inactivated by heat treatment. Thanks to genetic improvements, the content of these ANFs 
in modern pea cultivars has now decreased and the major concern is related rather to their content of non-starch polysaccharides (NSP) and nutrients not digested in the upper part of the gastrointestinal tract (GIT) and, therefore, possibly metabolized by microbiota in the posterior parts of GIT, promoting excessive fermentation.

The digestibility of pea nutrients in broilers increases with decreasing particle size (Kluth, 2011) and with pelleting (Carré et al., 1991; Grosjean et al., 1999). It can also be affected by extrusion (Alonso et al., 2000; Leontowicz et al., 2001; Diaz et al., 2006, Nalle et al., 2011). Extrusion is a process where the feed is subjected to mixing, shearing and heating under high pressure before the extrudate is forced through a die. The main benefits of the extrusion process include disruption of the grain structure, starch gelatinization, denaturation of proteins, and inactivation of heat-labile ANFs like protease inhibitors and lectins (van der Poel, 1992; Alonso et al., 2000; Leontowicz et al., 2001; Nalle et al., 2011). Extrusion has been reported to have positive effects on in vitro protein and starch digestibility and on the nutritional value of peas in rats (Alonso et al., 2000; Leontowicz et al., 2001). In chickens, extrusion of peas increased ileal starch digestibility, but had no effect on apparent ileal protein digestibility or apparent metabolizable energy (Nalle et al., 2011). Information on the effect of pea extrusion and pea level in broiler diets on the intestinal epithelium and activity of GIT microbiota are scarce. In our earlier study (Czerwinski et al., 2010), inclusion of $15 \%$ raw white-flowered pea into broiler diets did not affect short-chain fatty acid concentration in ileal digesta, but increased it in caecal digesta.

The aim of the study was to evaluate the effects of different levels of raw or extruded coloured-flower peas in pelleted broiler diets on growth performance, ileal digestibility of nutrients, activity of GIT microbiota and morphology of the small intestine.

\section{Material and methods}

\section{Material}

Round-seeded spring peas (Pisum sativum L.) cv. Milwa with pink flowers harvested in 2011 were purchased from a commercial supplier. Half of the seeds were extruded on a KMZ-2 single-screw extruder. The conditions during the extrusion process were: moisture about $22 \%$, exposition time $10 \mathrm{~s}$, temperature $110-160^{\circ} \mathrm{C}$, and pressure of $30 \mathrm{~kg} \cdot \mathrm{cm}^{-2}$.
Raw and extruded seeds were ground on a SKIOLD disc mill and analysed.

\section{Diets}

The isocaloric and isonitrogenous diets balanced in terms of lysine and sulphur amino acids were formulated to meet or exceed the requirements for broilers (Smulikowska and Rutkowski, 2005). The composition of diets was closely related to commercial practice, and was based on wheat and maize combined either with soyabean meal (control) or with soyabean meal and raw or extruded pea seeds as protein sources (Tables 1 and 2). All components of the diets were thoroughly mixed and the diets were pelleted $\left(50^{\circ} \mathrm{C}\right)$ in a CL-2 CPM laboratory pellet mill. Prior to pelleting, $10 \mathrm{~kg}$ portions of finisher diets were separated, $10 \mathrm{~g} \mathrm{TiO}_{2}$ per $\mathrm{kg}$ was added as an indigestible marker, the diets were again thoroughly mixed and pelleted. Diets with the marker were used for the digestibility trial.

\section{Birds and housing}

The experimental procedures were approved by the $3^{\text {rd }}$ Local Animal Care and Ethics Committee in Warsaw. A total of 200 one-day-old female broilers (Ross 308) were obtained from a local hatchery and randomly assigned to 25 cages ( 8 birds per cage). Room temperature was maintained at $30^{\circ} \mathrm{C}$ for the first 3 days and was thereafter gradually reduced according to normal management practice. A light cycle of $18 \mathrm{~h}$ light and $6 \mathrm{~h}$ darkness was maintained throughout the study; the birds had free access to feed and water. The chickens were assigned to 3 experimental groups, control (C) 24 birds, raw (RP) and extruded pea (EP), 88 birds each, and fed starter-type diets (first 3 days mash, later pellets; Table 1). On day 8, the broilers were weighed, and allocated to individual cages. Each bird was considered a replication. Broilers were fed starter-type diets until 14 days of life, then weighed and allocated to 9 experimental groups, each numbering 18 birds of a body weight close to the group average. The birds were fed experimental grower-type diets (Table 1) from day 15 to 28 , and finisher diets (Table 2) from day 29 to 35 .

\section{Sampling procedures}

The birds were weighed on day 8,15 and 35 after $4 \mathrm{~h}$ of feed deprivation. Feed consumption in the respective periods was measured and body weight gain (BWG) and feed conversion ratio (FCR) were calculated. The birds were fed the respective finisher diets containing $\mathrm{TiO}_{2}$ from 35 day to slaughter on day 37 . After slaughter the abdominal 
Table1. Composition of diets, $\mathrm{g} \cdot \mathrm{kg}^{-1}$ air dry matter

\begin{tabular}{|c|c|c|c|c|c|c|c|c|c|c|c|c|}
\hline \multirow{3}{*}{ Indices } & \multicolumn{12}{|c|}{ Period of feeding } \\
\hline & \multicolumn{3}{|c|}{$1-14$ day } & \multicolumn{9}{|c|}{ 15-35 day } \\
\hline & $\bar{C}$ & $\mathrm{R}_{10}$ & $E_{10}$ & $\bar{C}$ & $\mathrm{R}_{15}$ & $\mathrm{R}_{20}$ & $\mathrm{R}_{25}$ & $\mathrm{R}_{30}$ & $E_{15}$ & $\mathrm{E}_{20}$ & $\mathrm{E}_{25}$ & $\mathrm{E}_{30}$ \\
\hline \multicolumn{13}{|l|}{ Peas } \\
\hline raw & - & 100 & - & - & 150 & 200 & 250 & 300 & - & - & - & - \\
\hline extruded & - & - & 100 & - & - & - & - & - & 150 & 200 & 250 & 300 \\
\hline Soyabean meal & 340.0 & 311.9 & 310.8 & 310.8 & 268.6 & 254.5 & 240.4 & 226.2 & 289.6 & 204.1 & 144.6 & 183.2 \\
\hline Wheat & 405.0 & 333.4 & 334.5 & 424.0 & 316.3 & 280.7 & 245.0 & 209.3 & 445.4 & 362.3 & 316.7 & 388.6 \\
\hline Rapeseed oil & 20 & 20 & 20 & 30 & 30 & 30 & 30 & 30 & 30 & 30 & 30 & 30 \\
\hline Maize & 200 & 200 & 200 & 200 & 200 & 200 & 200 & 200 & 200 & 200 & 200 & 200 \\
\hline $\mathrm{NaCl}$ & 3 & 3 & 3 & 3 & 3 & 3 & 3 & 3 & 3 & 3 & 3 & 3 \\
\hline Limestone & 11 & 11.2 & 11.2 & 11.5 & 11.7 & 11.8 & 11.9 & 12.0 & 11.7 & 11.8 & 11.9 & 12.0 \\
\hline Mono-Ca-phosphate & 13 & 13 & 13 & 12 & 12.3 & 12.2 & 12.1 & 12.1 & 12.3 & 12.2 & 12.1 & 12.1 \\
\hline L-Lys (78\%) & 1.4 & 0.7 & 0.7 & 1.9 & 1.0 & 0.6 & 0.3 & - & 1.0 & 0.6 & 0.3 & - \\
\hline DL-Met $(98 \%)$ & 1.6 & 1.8 & 1.8 & 1.8 & 2.1 & 2.2 & 2.3 & 2.4 & 2.1 & 2.2 & 2.3 & 2.4 \\
\hline Mineral-vitamin premix $x^{2,3}$ & $5^{2}$ & $5^{2}$ & $5^{2}$ & $5^{3}$ & $5^{3}$ & $5^{3}$ & $5^{3}$ & $5^{3}$ & $5^{3}$ & $5^{3}$ & $5^{3}$ & $5^{3}$ \\
\hline \multicolumn{13}{|l|}{ Calculated, before pelleting } \\
\hline crude protein, $\mathrm{g} \cdot \mathrm{kg}^{-1}$ & 216 & 216 & 216 & 205 & 205 & 205 & 205 & 205 & 205 & 205 & 205 & 205 \\
\hline $\mathrm{ME}, \mathrm{MJ} \cdot \mathrm{kg}^{-1}$ & 12.0 & 12.0 & 12.1 & 12.4 & 12.4 & 12.4 & 12.4 & 12.4 & 12.4 & 12.4 & 12.4 & 12.4 \\
\hline \multicolumn{13}{|c|}{ Analysed, after pelleting, as fed } \\
\hline dry matter, $\mathrm{g} \cdot \mathrm{kg}^{-1}$ & 895 & 895 & 918 & 890 & 920 & 908 & 919 & 911 & 898 & 901 & 898 & 910 \\
\hline crude protein, $\mathrm{g} \cdot \mathrm{kg}^{-1}$ & 221 & 217 & 222 & 206 & 216 & 211 & 216 & 213 & 209 & 209 & 206 & 209 \\
\hline
\end{tabular}

${ }^{1}$ C-control, $R_{10}, R_{15}, R_{20}, R_{25}, R_{30}$ raw pea seeds; $E_{10}, E_{15}, E_{20}, E_{25}, E_{30}$ extruded pea seeds at amounts of 10, 15, 20, 25 and $30 \%$ diet, respectively; ${ }^{2}$ provided per kg diet; IU: 2 vit. A 12500 , vit. $D_{3} 5000$; mg: vit. $E 50$, vit. $B_{1} 3$, vit. $B_{2} 7.5$, biotin 0.2 , vit. $B_{6} 5$, vit. $B_{1} 0.025$, vit. $\mathrm{K}_{3} 3$, nicotinic acid 50; folic acid 1.75, pantothenic acid 12.5, choline 400, Mn 90, Zn 90, Se 0.3, Co 0.3, Cu 15, Fe 60, J 1; g: Ca 0.95; U:

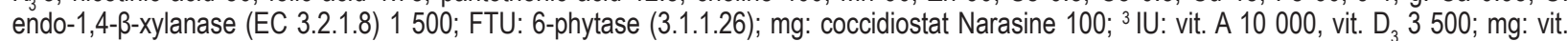
$E 50$, vit. $B_{1} 2$, vit. $B_{2} 6$, biotin 0.183 , vit. $B_{6} 4$, vit. $B_{12} 0.02$, vit. $K_{3} 2.5$; nicotinic acid 50 ; folic acid 1.25 , pantothenic acid 10 , choline 400 , Mn 80, Zn 80, Se 0.3, Cu 12.5, Fe 50, J 0.8, Co 0.3; g: Ca 0.95; U: endo-1,4- $\beta$ xylanase (EC 3.2.1.8) 1500; FTU: 3-phytase (EC 3.1.3.8) 500; $\mathrm{mg}$ : coccidiostat Narasine 70

Table 2. Composition of finisher-type diets, fed between $29-35$ day of life, $\mathrm{g} / \mathrm{kg}$ air dry matter ${ }^{1}$

\begin{tabular}{|c|c|c|c|c|c|c|c|c|c|}
\hline Indices & $\mathrm{C}$ & $\mathrm{RP}_{15}$ & $\mathrm{RP}_{20}$ & $\mathrm{RP}_{25}$ & $\mathrm{RP}_{30}$ & $E P_{15}$ & $\mathrm{EP}_{20}$ & $\mathrm{EP}_{25}$ & $\mathrm{EP}_{30}$ \\
\hline \multicolumn{10}{|l|}{ Peas } \\
\hline raw & - & 150 & 200 & 250 & 300 & - & - & - & - \\
\hline extruded & - & - & - & - & - & 150 & 200 & 250 & 300 \\
\hline Soyabean meal & 281.2 & 238.9 & 224.7 & 210.5 & 196.5 & 237.3 & 222.4 & 207.8 & 193.1 \\
\hline Wheat & 455.8 & 348.2 & 312.9 & 276.9 & 241.0 & 349.8 & 315.2 & 279.6 & 244.4 \\
\hline Rapeseed oil & 30 & 30 & 30 & 30 & 30 & 30 & 30 & 30 & 30 \\
\hline Maize & 200 & 200 & 200 & 200 & 200 & 200 & 200 & 200 & 200 \\
\hline $\mathrm{NaCl}$ & 3 & 3 & 3 & 3 & 3 & 3 & 3 & 3 & 3 \\
\hline Limestone & 11.0 & 11.1 & 11.3 & 11.4 & 11.4 & 11.1 & 11.3 & 11.4 & 11.4 \\
\hline Mono-Ca-phosphate & 11 & 11.2 & 11.2 & 11.3 & 11.3 & 11.2 & 11.2 & 11.3 & 11.3 \\
\hline L-Lys (78\%) & 1.7 & 1.0 & 0.5 & 0.2 & - & 1.0 & 0.5 & 0.2 & - \\
\hline DL-Met $(98 \%)$ & 1.3 & 1.6 & 1.6 & 1.7 & 1.8 & 1.6 & 1.6 & 1.7 & 1.8 \\
\hline Mineral-vitamin premix ${ }^{2}$ & 5 & 5 & 5 & 5 & 5 & 5 & 5 & 5 & 5 \\
\hline \multicolumn{10}{|l|}{ Calculated, before pellting } \\
\hline crude protein & 195.0 & 195.0 & 195.0 & 195.0 & 195.0 & 195.0 & 195.0 & 195.0 & 195.0 \\
\hline $\mathrm{EM}, \mathrm{MJ} \cdot \mathrm{kg}^{-1}$ & 12.5 & 12.5 & 12.5 & 12.5 & 12.5 & 12.5 & 12.5 & 12.5 & 12.5 \\
\hline \multicolumn{10}{|l|}{ Analysed, after pelleting, as fed } \\
\hline dry matter, $\mathrm{g} \cdot \mathrm{kg}^{-1}$ & 943 & 943 & 947 & 888 & 910 & 869 & 867 & 904 & 895 \\
\hline crude protein, $\mathrm{g} \cdot \mathrm{kg}^{-1}$ & 201 & 207 & 207 & 197 & 196 & 183 & 186 & 191 & 189 \\
\hline starch, $\mathrm{g} \cdot \mathrm{kg}^{-1}$ & 338 & 352 & 361 & 328 & 322 & 330 & 333 & 338 & 337 \\
\hline trypsin inhibitor, $\mathrm{mg} \cdot \mathrm{Tl} / \mathrm{g}^{3}$ & 0.090 & 0.333 & 0.413 & 0.473 & 0.646 & 0.159 & 0.171 & 0.219 & 0.203 \\
\hline tannins, $\mathrm{g} \cdot \mathrm{kg}^{-1}$ & 0.499 & 0.651 & 0.699 & 0.692 & 0.791 & 0.624 & 0.627 & 0.678 & 0.737 \\
\hline $\mathrm{TiO}_{2}, \mathrm{~g} \cdot \mathrm{kg}^{-1}$ & 10.00 & 9.96 & 10.38 & 9.22 & 9.49 & 9.21 & 9.26 & 9.46 & 9.54 \\
\hline
\end{tabular}

${ }^{1} \mathrm{C}$-control, $R_{10}, R_{15}, R_{20}, R_{25}, R_{30}$ raw pea seeds; $E_{10} E_{15}, E_{20}, E_{25} E_{30}$ extruded pea seeds at amount of: 10, 15, 20, 25 and $30 \%$ diet, respectively; ${ }^{2}$ provided per kg diet; IU: vit $A 9000$, vit. $D_{3} 2500$; $\mathrm{mg}$ : vit. E 40 , vit. $\mathrm{B}_{1} 2.25$, vit. $\mathrm{B}_{2} 4.5$, biotin 0.1 , vit. $\mathrm{B}_{6} 3$, vit. $\mathrm{B}_{12} 0.015$, vit. $\mathrm{K}_{3} 2$, nicotinic acid 30 , folic acid 0.75, pantothenic acid 9.375, choline 300, Mn 70, Zn 60, Se 0.15, Cu 6, Fe 40, J 0.6, Co 0.25; g: Ca 1.31; EPU: endo-1,4- $\beta$-xylanase (EC 3.2.1.8) 1500; FTU: 3-phytase (EC 3.1.1.8) 500; ${ }^{3}$ trypsin inhibitor activity, expressed as mg pure trypsin inhibited per gram product 
cavity was opened and the liver, gizzard and leaf fat were excised and weighed. The luminal contents of the ileum ( $1 \mathrm{~cm}$ distal of Meckel's diverticulum to the ileocaecal junction) and caecum were pooled by segment for every two chickens and homogenized. Ileal digesta were sampled for DM, N total, starch, $\mathrm{TiO}_{2}, \mathrm{pH}$ and short-chain fatty acids (SCFA) analysis, caecal digesta only for $\mathrm{pH}$ and SCFA analysis. From seven randomly selected birds per group, $3 \mathrm{~cm}$ segments of the jejunum, starting $5 \mathrm{~cm}$ anterior to Meckel's diverticulum, were taken for histological examination.

The $\mathrm{pH}$ was measured immediately in the ileal and caecal contents mixed with deionized water $(1: 1 \mathrm{w} / \mathrm{w})$ using a digital $\mathrm{pH}$-meter (WTW $\mathrm{pH} / 340$, Germany) and $\mathrm{pH}$ standard WTW-82362 Weilheim (model STP4) at room temperature. The ileal and caecal digesta samples were converted to their respective sodium salts by adjusting $\mathrm{pH}$ to 8.2 with $1 \mathrm{M} \mathrm{NaOH}$ solution, and stored at $-20^{\circ} \mathrm{C}$ for further SCFA analysis.

\section{Histological analysis}

Segments of jejunal tissue were placed in Bouin's solution for 5 days, dehydrated and embedded in paraffin. Serial 5- $\mu \mathrm{m}$ histological sections were cut on a microtome, mounted on slides, stained with haematoxylin, counter-stained with eosin and examined under a light Zeiss Axio Star Plus (Carl Zeiss, Göttingen, Germany) microscope and image analysis programme Axio Visio LE Rel. 4,5 (Carl Zeiss, 2002-2005).

\section{Chemical analysis}

The chemical composition of the pea samples and the DM and $\mathrm{N}$ contents in diets and ileal digesta were determined according to AOAC (1990) methods. In the raw and extruded pea samples and $\mathrm{TiO}_{2}$-containing finisher type diets, the tannin content was evaluated according to the method of Jerumanis (1972) modified by Adams and Novellie (1975), while trypsin inhibitor activity (TIA) was analysed according to Kakade et al. (1974), and defined as mg pure trypsin inhibited per gram of sample. The $\mathrm{TiO}_{2}$ content in diets and ileal digesta was determined using the colorimetric method described by Short et al. (1996). The starch content in peas, diets, and ileal digesta was measured using a diagnostic assay kit for the beverage, food and agricultural industries (D-glucose GOPOD Format Assay Kit, Megazyme, Int.) based on the use of thermostable $\alpha$-amylase and amyloglucosidase. The SCFA analysis were done according to the procedure described by Barszcz et al. (2011) using isocaproic acid as an internal standard on a HP 5890 Series II gas chromatograph (Hewlett Packard, Waldbronn, Germany) with a flame-ionization detector (FID) and Supelco Nukol fused silica capillary column $(30 \mathrm{~m} \times 0.25 \mathrm{~mm}$ internal diameter, film $0.25 \mathrm{~mm}$ ). Helium was used as the carrier gas. The oven was initially kept at $100^{\circ} \mathrm{C}$ for $2 \mathrm{~min}$, then heated at $10^{\circ} \mathrm{C} / 10 \mathrm{~min}$ to $140^{\circ} \mathrm{C}$ and held for $20 \mathrm{~min}$. The injector temperature was maintained at $220^{\circ} \mathrm{C}$, while the detector was kept at $250^{\circ} \mathrm{C}$. The concentrations of individual SCFA were estimated in relation to an internal standard using a mixture of SCFA standard solutions.

\section{Calculations and statistical analysis}

Feed intake, body weight gain and feed conversion ratio were calculated separately for periods from days 8 to 14 and days 15 to 35 of life. The apparent ileal digestibility coefficients (AIDC) of nitrogen and starch in the diets were calculated using titanium dioxide as the indigestible marker, as shown below:

AIDC of pea diet $=\frac{\left.(\text { nutrient } / \mathrm{Ti})_{\text {diet }}-(\text { nutrient } / \mathrm{Ti})_{\text {id }}\right)}{(\text { nutrient } / \mathrm{Ti})_{\text {diet }}}$

where: (nutrient/Ti) ${ }_{\text {diet }}$ - ratio of nutrient to titanium in diet; (nutrient/Ti) ${ }_{\text {id }}-$ ratio of nutrient to titanium in ileal digesta.

The experimental groups were compared with the control group by one-way analysis of variance. The effects of pea extrusion and pea level were analysed as $2 \times 4$ factorial arrangement using the STATGRAPHICS ${ }^{\circledR}$ Centurion XVI ver. 16.1 .03 (19822010). All statements of significance are based on $P \leq 0.05$ and $P \leq 0.01$.

\section{Results}

The chemical composition of raw and extruded peas is shown in Table 3. The DM content of extruded pea was 4.6 percentage points higher than in raw pea. The content of crude protein, crude fat, ash, starch and tannins in dry matter was similar in raw and extruded pea. Trypsin inhibitor activity was reduced by $86 \%$ in extruded peas in comparison with raw ones. The TIA value in finisher diets was $0.09 \mathrm{mg} \cdot \mathrm{g}^{-1}$ in the control diet, and ranged from 0.333 to $0.646 \mathrm{mg} \cdot \mathrm{g}^{-1}$ in diets with raw peas, and from 0.159 to $0.203 \mathrm{mg} \cdot \mathrm{g}^{-1}$ in diets with extruded peas (Table 2). The tannin content in the control diet was $0.499 \mathrm{~g} \cdot \mathrm{kg}^{-1}$, in experimental diets it increased by $25 \%$ to $58 \%$ as the pea content increased. The starch content did not change with the different level of peas in the diets (Table 2). 
Table 3. Chemical composition of peas $\left(\mathrm{g} \cdot \mathrm{kg}^{-1} \mathrm{DM}\right)$ and trypsin inhibitor activity (TIA), $\mathrm{mg} \cdot \mathrm{g}^{-1}$

\begin{tabular}{lcc}
\hline Component & Raw peas & Extruded peas \\
\hline Dry matter, $\mathrm{g} \cdot \mathrm{kg}^{-1}$ (as fed) & 880.5 & 926.5 \\
Crude protein $(\mathrm{N} \times 6.25)$ & 236 & 229 \\
Crude fat & 11.5 & 12.1 \\
Ash & 30.7 & 30.4 \\
Starch & 342 & 346 \\
Tannins & 0.964 & 1.099 \\
TIA, $\mathrm{mg} \cdot \mathrm{g}^{-1}$ & 2.35 & 0.35 \\
\hline
\end{tabular}

${ }^{1}$ expressed as mg pure trypsin inhibited per gram product

Mortality during the experiment was low $(2.8 \%$ in first week of life and 4 birds by the end of the experiment) and was not related to experimental treatments. At the end of the first week, the chickens fed starter diets with extruded peas were slightly heavier than those fed the control diet, but during the second week there were no significant differences in growth performance between groups fed diets containing $10 \%$ raw or extruded peas and the control group (Table 4).

The performance of broilers fed diets with different levels of peas is shown in Table 5. The level

Table 4. Performance of broilers from 8 to 15 day of life

\begin{tabular}{lllll}
\hline $\begin{array}{l}\text { Dietary } \\
\text { treatments }\end{array}$ & $\begin{array}{l}\text { Initial body } \\
\text { weight, } \mathrm{g}\end{array}$ & $\begin{array}{l}\text { BWG, } \\
\mathrm{g}\end{array}$ & $\begin{array}{l}\text { Feed } \\
\text { intake, g }\end{array}$ & $\begin{array}{l}\text { FCR, } \\
\text { g feed/g BWG }\end{array}$ \\
\hline Control & $135.7^{\mathrm{A}}$ & 263.5 & 353.5 & 1.34 \\
$\mathrm{RP}_{10}$ & $139.3^{\mathrm{AB}}$ & 259.5 & 354.6 & 1.37 \\
$\mathrm{EP}_{10}$ & $143.4^{\mathrm{B}}$ & 270.3 & 360.8 & 1.34 \\
$\mathrm{SEM}$ & 1.51 & 4.54 & 5.49 & 0.015 \\
\hline
\end{tabular}

$\mathrm{RP}$ - raw peas, EP - extruded peas; ${ }^{\mathrm{AB}, \mathrm{ab}}$ means with different superscipts within columns are significantly different at $P \leq 0.01$ or $P \leq 0.05$, respectively

Table 5. Main effects of dietary treatments on performance of broilers between 15-35 day of life and on weight of selected organs at $37^{\text {th }}$ day of life ${ }^{1}$

\begin{tabular}{|c|c|c|c|c|c|c|c|}
\hline $\begin{array}{l}\text { Dietary } \\
\text { treatments }\end{array}$ & $\begin{array}{l}\text { Initial } \\
\text { BW, kg }\end{array}$ & $\begin{array}{l}\text { BWG, } \\
\mathrm{kg}\end{array}$ & $\begin{array}{l}\text { Feed } \\
\text { 'intake, } \\
\mathrm{kg}\end{array}$ & $\begin{array}{l}\text { FCR, kg } \\
\text { feed/kg } \\
\text { BWG }\end{array}$ & $\begin{array}{l}\text { Liver, } \\
\text { g/100 g } \\
\text { LBW }\end{array}$ & $\begin{array}{l}\text { Pancreas, } \\
\mathrm{g} \mathrm{mg/100} \mathrm{g} \\
\text { LBW }\end{array}$ & $\begin{array}{l}\text { Gizzard, } \\
\text { g/100g } \\
\text { LBW }\end{array}$ \\
\hline Control & 0.40 & 1.66 & 2.66 & 1.59 & 2.48 & 160 & 1.35 \\
\hline \multicolumn{8}{|c|}{ Main effects of peas $(P)$} \\
\hline raw & 0.40 & 1.67 & $2.62^{a}$ & $1.57^{\mathrm{a}}$ & 2.35 & 180 & $1.43^{\mathrm{B}}$ \\
\hline extruded & 0.41 & 1.67 & $2.68^{\mathrm{b}}$ & $1.60^{\mathrm{b}}$ & 2.40 & 170 & $1.32^{\mathrm{A}}$ \\
\hline \multicolumn{8}{|c|}{ Peas level, g/kg diet (L) } \\
\hline 150 & 0.40 & 1.67 & 2.62 & 1.57 & $2.50^{b}$ & 170 & $1.31^{\mathrm{A}}$ \\
\hline 200 & 0.40 & 1.66 & 2.65 & 1.60 & $2.39 \mathrm{ab}$ & 180 & $1.31^{\mathrm{A}}$ \\
\hline 250 & 0.40 & 1.66 & 2.62 & 1.58 & $2.26^{\mathrm{a}}$ & 180 & $1.41^{\mathrm{AB}}$ \\
\hline 300 & 0.41 & 1.70 & 2.71 & 1.60 & $2.36^{\mathrm{ab}}$ & 180 & $1.47^{\mathrm{B}^{*}}$ \\
\hline SEM & 0.009 & 0.028 & 30.043 & 0.017 & 0.076 & 7.3 & 0.054 \\
\hline Interaction (I & $(\mathrm{P} \times \mathrm{L}) \mathrm{ns}$ & sns & ns & 0.025 & ns & ns & ns \\
\hline
\end{tabular}

LBW - live body weight before slaughter at $37^{\text {th }}$ day of life; ${ }^{1}$ within columns, for each main effect, means with different superscipts are significantly different at $P \leq 0.01$ or $P \leq 0.05$, respectively; ${ }^{*}$ significantly different from control group at $P \leq 0.05$; ns - not significant of peas in the diets did not significantly affect BWG, feed intake, or FCR. Chickens fed diets with extruded peas had a similar BWG, but consumed more feed $(P \leq 0.05)$ and had a worse FCR $(P \leq 0.05)$ than chickens fed diets with raw peas. A better FCR was noted in only two groups, with $15 \%$ and $25 \%$ raw peas, and for this reason the interaction was significant. The weight of the gizzard was lower in birds fed diets with extruded peas in comparison with raw peas $(P \leq 0.01)$. It increased with the higher levels of peas in the diets, but was significantly larger than in control birds only in the groups with the highest level of peas. There were no differences due to dietary treatments in the weight of the pancreas, the fluctuations in the relative weights of the liver were inconclusive.

The apparent ileal digestibility of dry matter (AIDDM) and nitrogen (AIDN), as well as the ileal digestibility of starch (IDS) was measured in 37-day-old chickens and is shown in Table 6. The AIDDM was lower in the pea diets than in the control $(P \leq 0.05)$. AIDDM decreased linearly as the content of raw peas increased, but did not depend on the level of extruded peas in diets; due to this the interaction between dietary treatments was significant $(P \leq 0.01)$. Neither extrusion of peas nor its dietary level affected AIDN coefficients, which were on average 0.79 in birds fed pea diets and 0.787 in birds fed the control diet. The coefficient of ileal digestibility of starch was 0.835 in the control group, while in chickens fed pea diets, it was higher by 2 percentage points $(P \leq 0.01)$. IDS increased as the level of peas in the diet rose (Table 6).

Table 6. Main effects of dietary treatments on apparent ileal digestibility of dry matter (AIDDM), nitrogen (AIDN) and ileal starch digestibility (IDS) coefficients in 37-day-old chickens ${ }^{1}$

\begin{tabular}{llll}
\hline $\begin{array}{l}\text { Dietary } \\
\text { treatments }\end{array}$ & AIDDM & AIDN & IDS \\
\hline Control & 0.686 & 0.787 & 0.835 \\
Main effects of peas $(P)$ & & & \\
$\quad$ raw & $0.656^{\mathrm{B}^{*}}$ & 0.784 & $0.857^{*}$ \\
$\quad$ extruded & $0.636^{\mathrm{A}^{*}}$ & 0.796 & $0.854^{*}$ \\
& & & \\
Peas level, g $\cdot \mathrm{kg}^{-1} \operatorname{diet}(L)$ & & & \\
150 & $0.656^{*}$ & 0.784 & $0.851^{\mathrm{A}^{*}}$ \\
200 & $0.642^{*}$ & 0.784 & $0.854^{\mathrm{AB}}$ \\
250 & $0.644^{*}$ & 0.790 & $0.856^{\mathrm{BC}^{*}}$ \\
300 & $0.643^{*}$ & 0.802 & $0.861^{\mathrm{C}^{*}}$ \\
SEM & 0.0025 & 0.0267 & 0.0068 \\
Interaction $P \times \mathrm{L}(P$ value $)$ & 0.01 & $\mathrm{~ns}$ & $\mathrm{~ns}$ \\
\hline
\end{tabular}

${ }^{1}$ within columns, for each main effect, means with different superscipts are significantly different at $P \leq 0.01$ or $P \leq 0.05$, respectively;; * significantly different from control at $P \leq 0.05$; ns - not significant 
The concentrations of short-chain fatty acids and the $\mathrm{pH}$ in ileal and caecal digesta are shown in Tables 7 and 8 , respectively. The total SCFA concentration in ileal digesta averaged $27.3 \mu \mathrm{mol} \cdot \mathrm{g}^{-1}$ in the control group and was slightly lower in birds fed the diets with raw peas, but higher in birds fed extruded peas, the difference between raw and extruded peas was significant $(P \leq 0.05)$. The major component of SCFA was acetate, $90 \%$ on average, and the minor components were propionate, butyrate, and isobutyrate $4 \%, 3.6 \%$ and $2.5 \%$, on average; valerate and isovalerate were present in small amounts and were not detected in all samples. The $\mathrm{pH}$ value did not differ significantly among treatments and averaged 6.76 (Table 7).

Table 7. Main effects of dietary treatments on short-chain fatty acids (SCFA) concentration $\left(\mu \mathrm{mol} \cdot \mathrm{g}^{-1}\right.$ ) and $\mathrm{pH}$ in ileal digesta in 37-day-old chickens $^{1}$

\begin{tabular}{|c|c|c|c|c|c|c|}
\hline $\begin{array}{l}\text { Dietary } \\
\text { treatments }\end{array}$ & $\begin{array}{l}\text { Total } \\
\text { SCFA }\end{array}$ & $\begin{array}{l}\text { Ace- } \\
\text { tate }\end{array}$ & $\begin{array}{l}\text { Propio- } \\
\text { nate }\end{array}$ & $\begin{array}{l}\text { Buty- } \\
\text { rate }\end{array}$ & $\begin{array}{l}\text { Isobu- } \\
\text { tyrate }\end{array}$ & $\mathrm{pH}$ \\
\hline Control & 27.3 & 24.4 & 1.4 & 1.1 & 0.7 & 6.73 \\
\hline \multicolumn{7}{|c|}{ Main effects of peas $(P)$} \\
\hline raw & $26.4^{a}$ & $23.7^{\mathrm{a}}$ & 1.2 & $1.1^{\mathrm{B}}$ & 0.7 & 6.73 \\
\hline extruded & $29.6^{b}$ & $26.9^{b}$ & 1.1 & $0.9^{A}$ & 0.7 & 6.81 \\
\hline \multicolumn{7}{|c|}{ Peas level, $\mathrm{g} \cdot \mathrm{kg}^{-1} \operatorname{diet}(L)$} \\
\hline 150 & 27.0 & 24.6 & 1.0 & 1.0 & 0.7 & 6.82 \\
\hline 200 & 26.8 & 24.1 & 1.3 & 1.0 & 0.7 & 6.59 \\
\hline 250 & 28.1 & 25.4 & 1.2 & 1.0 & 0.7 & 6.65 \\
\hline 300 & 29.9 & 27.2 & 1.1 & 1.0 & 0.7 & 7.02 \\
\hline SEM & 2.11 & 1.94 & 0.17 & 0.08 & 0.04 & 0.197 \\
\hline
\end{tabular}

${ }^{1}$ within columns, for each main effect, means with different superscipts are significantly different at $P \leq 0.01$ or $P \leq 0.05$, respectively; all interactions insignificant

Table 8. Results of control group and main effects of dietary treatments on short-chain fatty acids (SCFA) concentration $\left(\mu \mathrm{mol} \cdot \mathrm{g}^{-1}\right)$ and $\mathrm{pH}$ in caecal digesta in 37-day-old chickens ${ }^{1}$

\begin{tabular}{|c|c|c|c|c|c|c|c|c|}
\hline $\begin{array}{l}\text { Dietary } \\
\text { treatments }\end{array}$ & $\begin{array}{l}\text { Total } \\
\text { SCFA }\end{array}$ & $\begin{array}{l}\text { Ace- } \\
\text { tate }\end{array}$ & $\begin{array}{l}\text { Pro- } \\
\text { pionate }\end{array}$ & $\begin{array}{l}\text { Buty- } \\
\text { rate }\end{array}$ & $\begin{array}{l}\text { - Isobu- } \\
\text { tyrate }\end{array}$ & $\begin{array}{l}\text { Vale- } \\
\text { rate }\end{array}$ & $\begin{array}{l}\text { Isova- } \\
\text { lerate }\end{array}$ & $\mathrm{pH}$ \\
\hline Control & 160.5 & 116.1 & 7.2 & 33.3 & 0.98 & 1.9 & 1.0 & 6.24 \\
\hline \multicolumn{9}{|c|}{ Main effects of peas $(P)$} \\
\hline raw & $153.8^{\mathrm{B}}$ & $113.9^{B}$ & 6.3 & 29.8 & $1.1^{\mathrm{B}}$ & 1.5 & $1.1^{\mathrm{B}}$ & 6.50 \\
\hline extruded & $140.0^{A^{*}}$ & $A^{*} 100.4^{A}$ & 6.1 & 30.5 & $0.8^{\mathrm{A}}$ & 1.4 & $0.9^{A}$ & 6.35 \\
\hline \multicolumn{9}{|c|}{ Peas level, $\mathrm{g} \cdot \mathrm{kg}^{-1} \operatorname{diet}(L)$} \\
\hline 150 & 152.3 & 109.7 & 6.5 & $32.7^{b}$ & 0.9 & 1.6 & 0.9 & $6.36^{a}$ \\
\hline 200 & 151.1 & 111.4 & 6.7 & $29.6^{\mathrm{ab}}$ & b 1.0 & 1.6 & 1.0 & $6.20^{a}$ \\
\hline 250 & $138.9^{*}$ & 100.1 & 5.0 & $30.7^{\mathrm{ab}}$ & 0.9 & 1.3 & 0.9 & $6.44^{\mathrm{ab}}$ \\
\hline 300 & $145.4^{*}$ & 107.4 & 6.6 & $27.7^{\mathrm{a}}$ & a 1.1 & 1.5 & 1.2 & $6.68^{b^{*}}$ \\
\hline SEM & 6.07 & $7 \quad 4.73$ & 0.76 & 1.75 & 0.10 & 0.16 & 0.14 & 0.133 \\
\hline $\begin{array}{l}\mathrm{P} \times \mathrm{L} \\
\quad(P \text { value })\end{array}$ & ns & 0.04 & ns & ns & ns & ns & ns & ns \\
\hline
\end{tabular}

${ }^{1}$ within columns, for each main effect, means with different superscipts are significantly different at $P \leq 0.01$ or $P \leq 0.05$; * significantly different from control at $P \leq 0.05$; ns - not significant
Table 9. Main effects of dietary treatments on morphometry of jejunum mucosa in 37-day-old chickens

\begin{tabular}{lllll}
\hline $\begin{array}{l}\text { Dietary } \\
\text { treatments }\end{array}$ & $\begin{array}{l}\text { Villus } \\
\text { height, } \\
\mu \mathrm{m}\end{array}$ & $\begin{array}{l}\text { Villus } \\
\text { width, } \\
\mu \mathrm{m}\end{array}$ & $\begin{array}{l}\text { Crypt } \\
\text { depth, } \\
\mu \mathrm{m}\end{array}$ & $\begin{array}{l}\text { Tunica } \\
\text { muscularis } \\
\text { width, } \mu \mathrm{m}\end{array}$ \\
\hline $\begin{array}{l}\text { Control } \\
\text { Main effects of peas }(P)\end{array}$ & 1047 & 192 & 170 & 186 \\
$\quad$ raw & 967 & 187 & 166 & 183 \\
$\quad$ extruded & 935 & 188 & 165 & 179 \\
& & & & \\
Peas level, $\mathrm{g} \cdot \mathrm{kg}^{-1}$ & diet $(L)$ & & & \\
150 & 993 & 188 & 164 & 182 \\
200 & 972 & 195 & 170 & 183 \\
250 & 902 & 188 & 164 & 180 \\
300 & 937 & 181 & 164 & 179 \\
SEM & 41.8 & 7.4 & 2.8 & 5.5 \\
\hline
\end{tabular}

all differences insignificant

The total SCFA concentration in caecal digesta in the control group was $160.5 \mu \mathrm{mol} \cdot \mathrm{g}^{-1}$. In chickens fed diets with extruded peas, the total SCFA concentration was lower than in the control group and lower than in chickens fed raw peas $(P \leq 0.01)$, mainly due to the lower concentration of acetate, but also of iso-butyrate and iso-valerate $(P \leq 0.01)$. The ratio of major components of SCFA did not depend on dietary treatments; the contents of acetate and butyrate were $73 \%$ and $20.6 \%$, on average, and the minor components were propionate, $4.2 \%$ on average, followed by small amounts of valerate, isovalerate and isobutyrate. The $\mathrm{pH}$ of the caecal content of the control group was 6.24 and increased as the dietary pea level rose, but only in the group fed $30 \%$ peas was the $\mathrm{pH}$ significantly higher $(P \leq 0.05)$ than in the control and groups with lower pea levels (Table 8).

The villous height, villous width, crypt depth and tunica muscularis width of the jejunal mucosa in control birds were, on average, 1047, 192, 170 and $186 \mu \mathrm{m}$, respectively. The values were numerically smaller in the experimental groups, but there were no significant effects of dietary treatments on the morphometry of jejunal walls (Table 9).

\section{Discussion}

The primary concern with the use of peas in broiler diets is related to tannins and protease inhibitors, which can adversely affect nutrient utilization and performance in broilers (Castell et al., 1996; Smulikowska et al., 2001). The tannin content of seeds greatly depends on the intensity of flower colour and is lower in white-flowered than in coloured-flower peas. In older Polish varieties, the content of tannins in white-flowered peas was from 1.57 to $2.63 \mathrm{~g} \cdot \mathrm{kg}^{-1}$, in coloured-flower peas, 
from 7.17 to $8.02 \mathrm{~g} \cdot \mathrm{kg}^{-1}$ (Gdala et al., 1992); ten years later, white-flowered peas contained from 0.22 to $0.27 \mathrm{~g} \cdot \mathrm{kg}^{-1}$, coloured-flower peas, from 7.26 to $12.11 \mathrm{~g} \cdot \mathrm{kg}^{-1}$ (Smulikowska et al., 2001). Grosjean et al. (1999) reported that white peas contained from 0.04 to 0.14 , while coloured ones from 0.55 to 7.45 $\mathrm{g}$ tannin per kilogram DM. The results of the former study from our laboratory indicated that a high tannin content in peas may lower the digestibility of protein and the metabolizability of energy in rats and chickens (Smulikowska et al., 2001), while Grosjean et al. (1999) found a negative correlation between tannin content and AME value measured in adult cockerels. The seeds of pink-flowered cv. Milwa harvested in 2011, used in the current study, contained a rather low amount of tannins $\left(0.96 \mathrm{~g} \cdot \mathrm{kg}^{-1}\right)$, which did not change after extrusion. The tannin content in the control diet was $0.499 \mathrm{~g} \cdot \mathrm{kg}^{-1}$, and in the experimental diets it increased by $25 \%$ to $58 \%$ as the level of peas rose, but this did not interfere with the performance of chickens. It seems that the modern cultivars of peas with about $1 \mathrm{~g}$ of tannin $/ \mathrm{kg}$ seeds can be accepted as feed components for broilers.

The TIA value in older Polish varieties of peas ranged from 0.40 to 4.35 - on average $2.70 \mathrm{mg} \cdot \mathrm{g}^{-1}$ (Gdala et al., 1992), or from 0.50 to 1.25 - on average $1.01 \mathrm{mg} \cdot \mathrm{g}^{-1}$ (Smulikowska et al., 2001) and did not depend on flower colour. The TIA value reported by Zdunczyk et al. (1997) in white-flowered Polish varieties of peas averaged $2.10 \mathrm{mg} \cdot \mathrm{g}^{-1}$, while Grosjean et al. (1999) found an average TIA value of 2.68 for white peas and $1.31 \mathrm{mg} \cdot \mathrm{g}^{-1}$ for coloured peas. The TIA value in cv. Milwa used in the current study (2.35 mg TIA per $1 \mathrm{~g}$ ) was moderate and was within the limits reported for spring peas in many previous studies (reviewed by Huisman and Jansman, 1991). According to these authors, the acceptable trypsin inhibitor activity for soyabean meals ranges from 2 to $5 \mathrm{mg}$ TIA per gram. The TIA value found in peas used in the current study was within the range tolerated for soyabean meals, which are used as the most common high-protein feed for broilers.

In the present study, the extrusion process had no great effect on the protein, fat, ash, starch, or tannin contents in peas, but greatly reduced trypsin inhibitor activity, which in the extrudate was $85 \%$ lower than in raw seeds. The TIA value of diets containing extruded peas was, as expected, on average $42 \%$ lower than in diets containing raw peas, but both were much higher than in the control diet. According to van der Poel (1992), the degree of trypsin inhibitor inactivation after extrusion depends on the processing conditions (temperature and moisture content) and the cultivar used, being more effective under conditions of higher moisture and temperature and in round-seeded than in wrinkle-seeded peas. The efficacy of extrusion in lowering trypsin inhibitor activity in peas shown in literature ranges from 17\% (Nalle et al., 2011) through 55\% (Diaz et al., 2006), 87\% (Leontowicz et al., 2001), to $95 \%$ (Alonso et al., 2000). The last authors reported that also $65 \%$ of chymotrypsin inhibitors were inactivated and $98 \%$ of the haemagglutinating activity of peas disappears after the extrusion cooking applied in the study. Leontowicz et al. (2001) found that the haemagglutinating activity of peas is reduced by $75 \%$ after extrusion. The present study did not measure the haemagglutinating activity of peas, but it can be supposed that also most lectins were inactivated during extrusion.

High levels of trypsin inhibitors in feed inhibit gut proteases and stimulate the pancreas to enhance production of digestive enzymes, while high levels of lectins interfere with digestive and absorptive processes in the digestive tract and may damage the intestinal mucosa (Huisman and Jansman, 1991) and lead to substantial overgrowth of bacteria, especially E. coli in the intestine (Leontowicz et al., 2001). As stressed by Huisman and Jansman (1991), however, the threshold levels of these ANFs that can be tolerated without causing adverse effects in different species of farm animals are still disputable.

In the current study, pea protein substituted from $16 \%$ to $32 \%$ of soyabean meal and wheat protein. The TIA value in diets with raw peas was from 0.33 to $0.65 \mathrm{mg} \cdot \mathrm{g}^{-1}$, in diets with extruded peas, from 0.16 to $0.20 \mathrm{mg} \cdot \mathrm{g}^{-1}$, while in the control diet, $0.09 \mathrm{mg} \cdot \mathrm{g}^{-1}$. According to Szczurek (2009), the mean standardized ileal digestibility (SID) of essential amino acids of raw peas $(84.4 \%)$ in broilers is similar to that of wheat $(83.9 \%)$ and slightly lower than that of soyabean meal $(87.3 \%)$. In the present study, the apparent ileal digestibility of protein averaged $79 \%$, and was not affected by either the dietary pea level or the substantial decrease of trypsin inhibitor activity caused by pea extrusion. Thus may indicate that broilers can easily adapt to the trypsin inhibitor activity in the range present in the used peas. Nalle et al. (2011) also reported no improvement in ileal protein digestibility due to pea extrusion, while the ileal starch digestibility improved, but without effect on the apparent metabolizable energy of peas, which averaged $11.3 \mathrm{MJ} \cdot \mathrm{kg}^{-1} \mathrm{DM}$. The results of Alonso et al. (2000) and Leontowicz et al. (2001) support the conclusion that most of the lectins 
present in the raw peas used in the current study may have been inactivated during extrusion. The dietary treatments had no effect on the morphology of jejunal walls, however, indicating that the highest levels of lectins present in diet containing 30\% raw peas were not detrimental to the epithelium of the chickens' digestive tract.

In the current study, the ileal digestibility of dietary starch from pelleted pea-containing diets averaged $85.5 \%$, and slightly increased with the dietary pea level, but there was no effect of pea extrusion on this parameter. In the control group, ileal starch digestibility was $83.5 \%$; it seems that the increase in the level of tannins introduced with peas did not disturb starch digestion in chickens. The absence of an effect of pea level on ileal digestibility of the major nutrients was confirmed by performance results, which were similar in all groups. Similarly, Diaz et al. (2006) did not find significant differences in growth performance between broilers fed diets with $350 \mathrm{~g} \cdot \mathrm{kg}^{-1}$ of extruded or raw peas.

In the present study, the total SCFA concentration in ileal digesta was similar in chickens fed peas and in the control group, but it was slightly higher in birds fed extruded peas vs raw peas, and the difference was significant. In contrast, in the caecum the total SCFA concentration was lower in chickens fed diets with extruded peas than in the control group and lower than in chickens fed raw peas, mainly due to the lower concentration of acetate, but also of isobutyrate and iso-valerate. This points to changes in the degradability of substances reaching the small intestine and caecum. Generally, the digestibility of pea nutrients in broilers increases with decreasing particle size (Kluth, 2011). In cereals, the dietary fibre profile changes after extrusion - part of the starch is degraded into fractions resistant to enzymatic attack, while degradation of fibre macromolecules increases its solubility (Lue et al., 1991). Similar mechanisms may be involved during pea extrusion, probably slightly more starch reaches the end of the jejunum and can be fermented by the ileal microflora, but less of the low-molecular-weight fractions of dietary fibre reaches the caecum from extruded peas vs raw peas. The changes in SCFA concentrations in the ileum were small and had a negligible effect on bird performance. Smulikowska and Rutkowski (2005) recommended limiting the level of peas in broiler diets to $5 \%$ in the first 4 weeks of life and to $15 \%$ to the end of rearing. It seems that the limits can be extended to $10 \%$ in starter-type diets and $30 \%$ until the end of rearing when modern cultivars of peas are used and when they are included in pelleted diets.

\section{Conclusions}

It may be concluded that peas of the modern Milwa cultivar, which has a relatively low tannin content and moderate trypsin inhibitor activity, can be an effective protein source as a partial substitute of soyabean meal in broiler diets fed from the third week of life. The effects of pea extrusion on the ileal nutrient digestibility and activity of gut microbiota was too small to affect performance and the process does not seem to be economically justified.

\section{Acknowledgements}

Supported by funds from the programme 'Improvement of native plant protein feeds, their production, trade turnover and utilization in animal feed mixtures' of the Ministry of Agriculture and Rural Development of Poland.

\section{References}

Adams C.A., Novellie K., 1975. Composition and structure of protein bodies and spherosomes isolated from ungerminated seeds of sorghum bicolor (Linn.). Moench. Plant Physiol. 55, 1-6

Alonso R., Grant G., Devey P., Marzo F., 2000. Nutritional assessment in vitro and in vivo of raw and extruded peas (Pisum sativum L.). J. Agr. Food Chem. 48, 2286-2290

AOAC, 1990. Association of Official Analytical Chemists, Official Methods of Analysis. $15^{\text {th }}$ Edition. Washington, DC

Barszcz M., Taciak M., Skomiał J., 2011. A dose-response effects of tannic acid and protein on growth performance, caecal fermentation, colon morphology, and $\beta$-glucuronidase activity of rats. J. Anim. Feed Sci. 20, 613-625

Carré B., Beaufils E., Melcion J.P., 1991. Evaluation of protein and starch digestibilities and energy value of pelleted or unpelleted pea seeds from winter or spring cultivars in adult and young chickens. J. Agr. Food Chem. 39, 468-472

Castell A.G., Guenter W., Igbasan F.A., 1996. Nutritive value of peas for nonruminant diets. Anim. Feed Sci. Tech. 60, 209-227

Czerwinski J., Højberg O., Smulikowska S., Engberg R.M., Mieczkowska A., 2010. Influence of dietary peas and organic acids and probiotic supplementation on performance and caecal microbial ecology of broiler chickens. Brit. Poultry Sci. 51, 258-269

Diaz D., Morlacchini M., Masoero F., Moschini M., Fusconi G., Piva G., 2006. Pea seeds (Pisum sativum), faba beans (Vicia faba var. minor) and lupin seeds (Lupinus albus var. multitalia) as protein sources in broiler diets: effect of extrusion on growth performance. Ital. J. Anim. Sci. 5, 23-53

Gdala J., Buraczewska L., Grala W., 1992. The chemical composition of different types and varietes of pea and the digestion of their protein in pigs. J. Anim. Feed Sci. 1, 71-79

Grosjean F., Barrier-Guillot B., Bastianelli D., Rudeaux F., Bourdillon A., Peyronnet C., 1999. Feeding value of three categories of pea (Pisum sativum L.) for poultry. Anim. Sci. 69, 591-599

Huisman J., Jansman A.J.M., 1991. Dietary effects and some analytical aspects of antinutritional factors in peas (Pisum sativum), common beans (Phaseolus vulgaris) and soyabeans (Glycine max L.) in monogastric farm animals. A literature review. Nutr. Abstr. Rev. Ser. B 61, 901-921 
Jerumanis J., 1972. Über die Verönderung der Polyphenole in Verlauf des Mälzens und Maischens. Brauwissenschsft 25, 313-322

Kakade M.C., Rackis J.J., McGhee J.E., Puski G., 1974. Determination of trypsin inhibitor activity of soy products: collaborative analysis of an improved procedure. Cereal Chem. 51, 376-382

Kluth H., 2011. Relationship between feed particle size and digestibility of nutrients in poultry (in Germany). Proc. Soc. Nutr. Physiol. $20,157-161$

Leontowicz H., Leontowicz M., Kostyra H., Kulasek G., Gralak M.A., Krzemiński R., Podgurniak M., 2001. Effects of raw or extruded legume seeds on some functional and morphological gut parameters in rats. J. Anim. Feed Sci. 10, 169-183

Lue S., Hsieh F., Huff F., 1991. Extrusion cooking of maize meal and sugar beet fibre: effects of expansion properties, starch gelatinization and dietary fibre content. Cereal Chem. 68, 227-234

Nagaraj M.C.A., Wilson P., Hess J.B., Biligli S.F., 2007. Effect of high protein and all vegetable diets on the incidence and severity of pododermatitis in broiler chickens. J. Appl. Poultry Res. 16, 304-312

Nalle C.L., Ravindran G., Ravindran V., 2011. Extrusion of peas (Pisum sativum L.): Effects on the apparent metabolisable energy and ileal nutrient digestibility of broilers. Amer. J. Anim. Vet. Sci. 6, 25-30
Short F.J., Gorton P., Wiseman J., Boorman K.N., 1996. Determination of titanium dioxide added as an inert marker in chicken digestibility studies. Anim. Feed Sci. Tech. 59, 215-221

Smulikowska S., Pastuszewska B., Święch E., Ochtabińska A., Mieczkowska A., Nguyen V.C., Buraczewska L., 2001. Tannin content affects negatively nutritive value of pea for monogastrics. J. Anim. Feed Sci. 10, 511-523

Smulikowska S., Rutkowski A. (Editors), 2005. Recommended Allowances and Nutritive Value of Feedstuffs - Poultry Feeding Standards (in Polish). $5^{\text {th }}$ Edition, The Kielanowski Institute of Animal Physiology and Nutrition, PAS, Jabłonna (Poland)

STATGRAPHICS $®$, 1982-2010.Centurion XVI ver.16.1.03. Statistical Graphic System by Statistical Graphic Corporation

Szczurek W., 2009. Standardized ileal digestibility of amino acids from several cereal grains and protein-rich feedstuffs in broiler chickens at the age of 30 days. J. Anim. Feed Sci. 18, 662-676

van der Poel A.F.B., 1992. Twin-screw extrusion of two pea varieties: Effects of temperature and moisture level on antinutitional factors and protein dispersibility. J. Sci. Food Agric. 58, 83-87

Zduńczyk Z., Godycka I., Amarowicz R., 1997. Chemical composition and content of antinutritional factors in Polish cultivars of peas. Plant Food Hum. Nutr. 50, 37-45 